\title{
The nesting success of green turtles on beaches at Kazanli, Turkey
}

\author{
Stephanie J. Coley and Andrew C. Smart
}

The green turtle Chelonia mydas is one of two marine turtle species to nest in Turkey. Its three main nesting beaches are in eastern Turkey, with possibly the densest congregation of nesting turtles in the Mediterranean being found at Kazanli. However, beach erosion, hatchling predation, agricultural encroachment and chemical pollution mean that the future of the Kazanli nest site is uncertain. The Turkish Society for the Protection of Nature (Dogal Hayati Koruma Dernegi) is making valiant efforts to protect all the turtle nesting beaches in Turkey but lacks detailed information on the numbers of nesting turtles on many beaches. This paper describes a short study of nesting turtles at Kazanli during 1990 and makes recommendations for the conservation of the nesting beach.

\section{Introduction}

Nesting sites of marine turtles in the Mediterranean are under threat due to pollution, land reclamation, sand extraction and increased tourist development, which has been associated with reduced numbers of nesting adults and emerging hatchlings. Development for tourism has been particularly apparent on the Greek island of Zakynthos (Margaritoulis, 1982; Arianoutsou, 1988; Warren and Antonpoulou, 1990), where problems led to confrontation between local people and conservation groups (Anon., 1990). The disruption of nesting due to tourism is a relatively new problem in the Mediterranean and has affected both loggerhead Caretta caretta nest sites, notably in Greece and Turkey, and Chelonia mydas nest sites in Cyprus (Groombridge, 1990). In Turkey, Chelonia mydas has been little affected by tourism because of its restricted distribution, but populations have been depleted by hunting in the recent past (Sella, 1982). More than 25,000 animals were taken from Turkish beaches at Mersin (probably Kazanli) and south of Adana (Akyatan) between 1952 and 1965. Sella (1982) also reported fishing in the Gulf of
Iskenderun as late as 1972 (annual catch 1200). In Turkey, problems due to tourism are greatest on the west Mediterranean coast and, until recently, conservation measures have concentrated on these sites. Turkey has 17 turtle nesting sites along the Mediterranean coast that are recognized as needing protection (Baran and Kasparek, 1989). Five have been designated Specially Protected Areas by the Turkish Government (Whitmore et al., 1990).

Nesting of C. mydas is known on the west (Demetropoulos and Hadjichristophorou, 1989) and north (Groombridge and Whitmore, 1989) coasts of Cyprus and the eastern Turkish Mediterranean coastline (Groombridge, 1990; Baran and Kasparek, 1989). In Turkey, the three most important sites for C. mydas are in the east: Kazanli, Akyatan, and Samandagi. Akyatan is controlled by the Department of Forestry and relatively unaffected by human activities, but Samandagi and Kazanli are threatened. Kazanli has a high nesting density relative to other Mediterranean beaches and is threatened by photopollution, pollution by tar and litter, chemical pollution and erosion of the beach (Baran and Kasparek, 1989). This paper describes research undertaken for the Turkish Society for the Protection of Nature 
(DHKD) at Kazanli during July 1990. The project investigated nesting success of $C$. mydas, examined the effect of agricultural and industrial development in the area and recommended priorities for management of the region.

\section{Study area}

Kazanli lies approximately $10 \mathrm{~km}$ east of Mersin and is the furthest west of the three important C. mydas nest sites in Turkey (Figure 1). Kazanli is dominated by the presence of the Soda Sanyaii factory immediately to the north, which is lit throughout the night. The authors followed the numbering of beaches adopted by Sarigul and Langeveld (1988), separating the Kazanli beaches into four (Figure 2). The total length of all four beaches is approximately $4 \mathrm{~km}$. Kazanli I (K1) makes up the majority (Figure 2), approximately 2.5 $\mathrm{km}$ of gentle sloping beach with no dunes. Kazanli II (K2) is relatively flat with a rough road separating the beach from dunes and ponds, which support a diverse reptile, amphibian and invertebrate fauna. The main nesting area, Kazanli III (K3), is only $605 \mathrm{~m}$ long. The entire length of $\mathrm{K} 3$ is fenced, separating the beach from an area where vegetables are grown by local farmers. K3 has $99 \mathrm{~m}$ of flat beach in the west; $239 \mathrm{~m}$ of high manmade dunes built as wind breaks; 73 m of 'natural' dune and $194 \mathrm{~m}$ of narrow beach, which runs into a stony area at the base of a jetty. This jetty separates the eastern end of K3 from Kazanli IV (K4), which lies within the confines of the Soda Sanyaii Factory. K4 has a man-

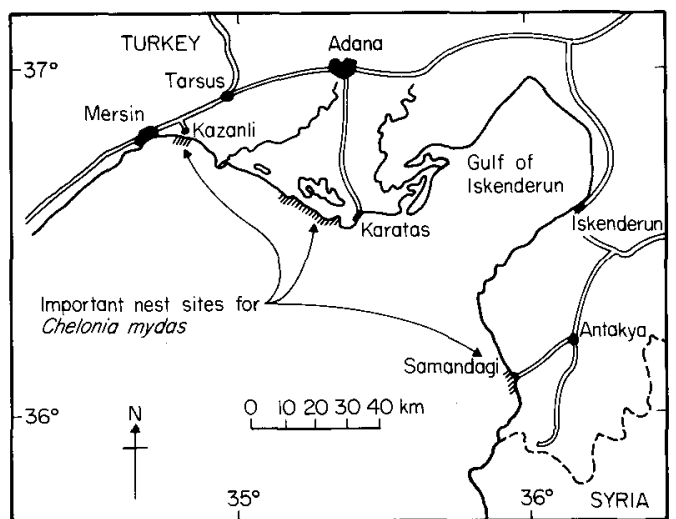

Figure 1. Map of eastern Turkey showing main nest sites for C. mydas in Turkey

made cliff to the north and a smaller jetty to the east. All four beaches suffer from photopollution and litter. Detailed descriptions can be found in Smart and Coley (1990), Baran and Kasparek (1989) and Sarigul and Langeveld (1988), and large-scale maps of each of the four beaches in Smart and Coley (1990).

\section{Methods}

Initial daytime surveys of the beach showed a concentration of abandoned body pits on $\mathrm{K} 3$. This was taken to indicate the area of maximum turtle activity and observations concentrated on this area. The following description of methods is based on monitoring of $\mathrm{K} 2$ and $\mathrm{K} 3$, which supported the majority of nesting activity. K1 and K4 were monitored infre-

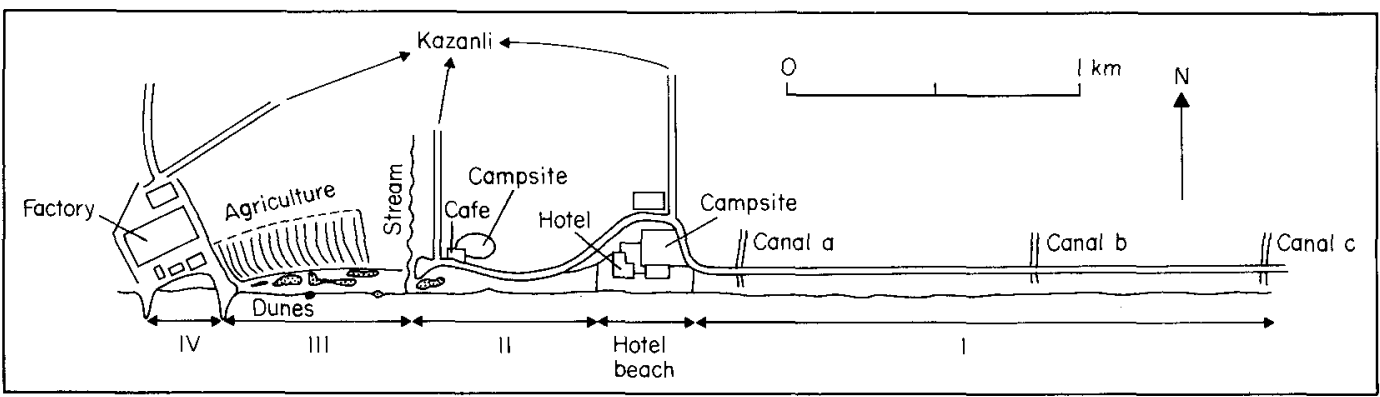

Figure 2. Map showing Kazanli beaches. 


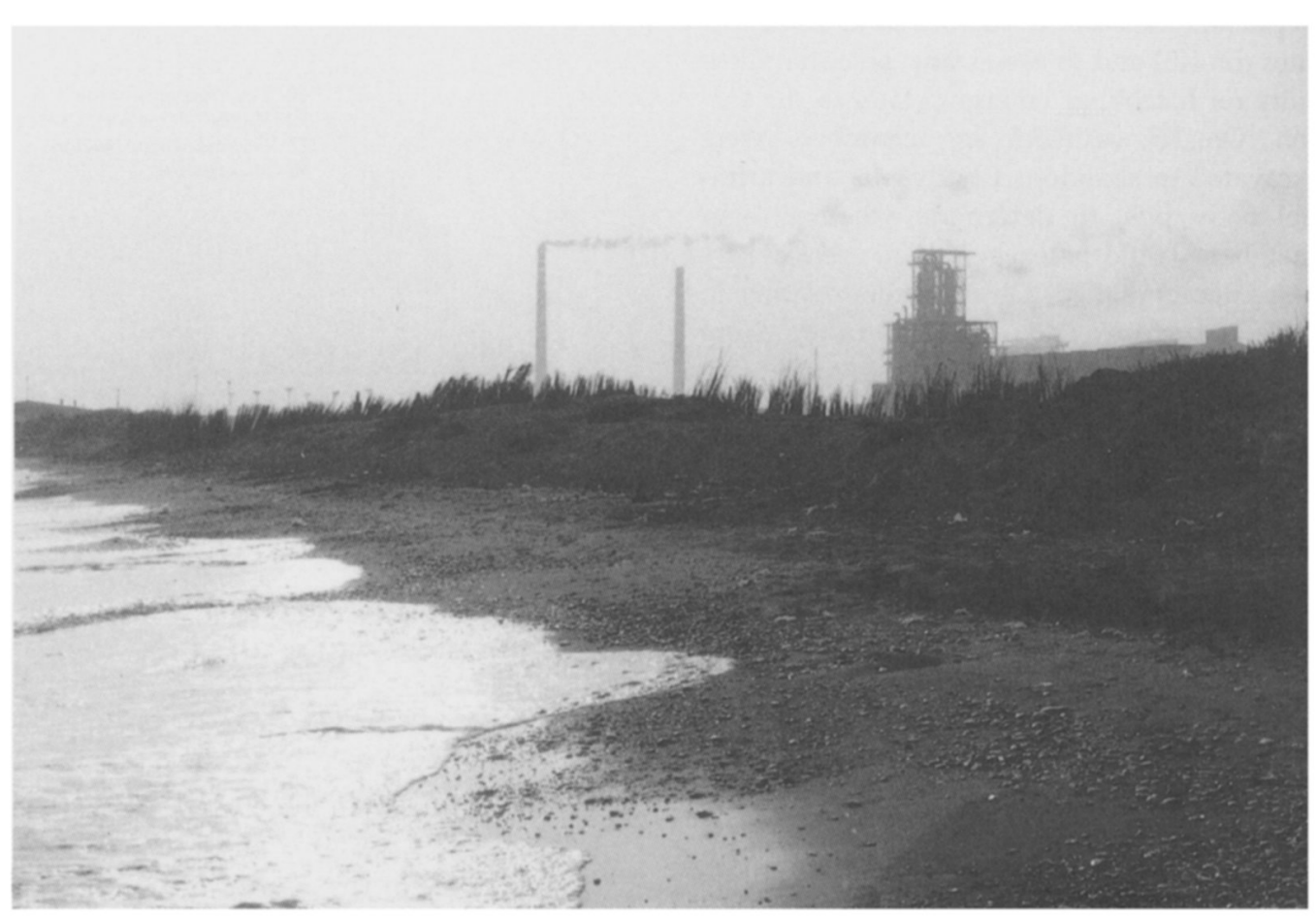

The nesting beach at Kazanli, showing the factory.

quently, depending on available personnel. Beaches were monitored between $22.00 \mathrm{~h}$ and $06.00 \mathrm{~h}$ (approximately). Observation commenced on $\mathrm{K} 2$, observers walking to the central dune region of $\mathrm{K} 3$, from where most of $\mathrm{K} 3$ could be viewed without presenting a silhouette to the sea. At intervals of approximately 30 minutes observers walked the length of both beaches. Tracks or turtles were followed carefully to minimize disturbance to emerging turtles. Observations were made without torches except for the use of a thin beam to establish the presence of eggs. Turtles were left undisturbed for as long as possible and only approached when digging of the egg pit had commenced. Approaches were always made by crawling behind the turtle to a point where it could be observed without risk of any disturbance interrupting nesting behaviour. Once a turtle returned to the sea, incoming and return tracks were marked.

When possible, counts of numbers of eggs laid and curved carapace length (from the edge of the nuchal scute to the most posterior process of the carapace) were recorded, and turtles were tagged by a research team from Dokus Eylül University at Izmir. Unstable sand made counting of eggs difficult because of the danger of sand falling into the egg chamber. When the turtle's rear flippers allowed easy access egg numbers were recorded, but generally, once laying was confirmed, turtles were checked for tags and left to camouflage the nest undisturbed. This enabled as many turtles as possible to be monitored and avoided the possibility of observers causing sand to collapse into the egg chamber.

Track records were taken on $\mathrm{K} 2$ and $\mathrm{K} 3$ every morning at $06.00 \mathrm{~h}$ before people disturbed the beach. The location of each emergence was recorded and an assessment made of the outcome. Three possible outcomes were defined: a successful nest; a failed nest attempt (where digging was attempted but the nest abandoned); and emergence with no attempt at digging (defined here as a ' $U$ '-turn).

Beaches were walked during daylight and night to assess differences in topography, the 
depth and moisture content of sand at nesting sites (on K3) and to assess any potential difficulty for hatchlings emerging later in the season. On K3, artificial egg chambers were excavated in abandoned body pits and artificial body pits, to determine whether 'eggchambers' could be excavated in areas where nest attempts failed. Observations relating to dune structure and photopollution were recorded to assess possible effects on nesting or hatchling emergence.

\section{Results}

Observations of emerging turtles and track records

There was no evidence of C. mydas being disturbed by the attention of observers from the project. Observation effort varied over the project, with researchers from Dokus Eylül University at Izmir assisting when possible. Results from observations are given in Table 1. Nesting C. mydas laid an average of 122 eggs \pm 17 (meant standard error, seven records) and

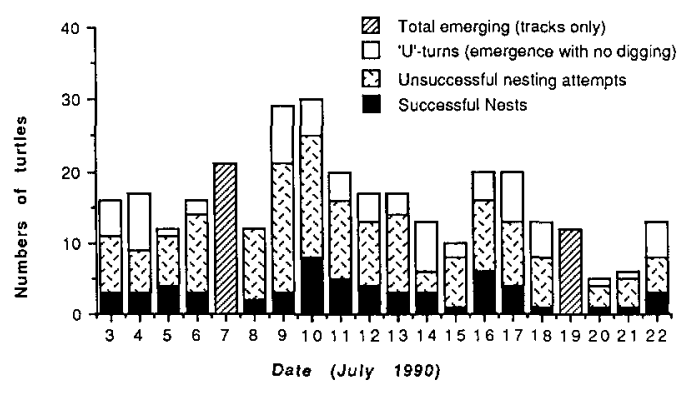

Figure 3. Turtle behaviour from track records over the study period on Kazanli III (K3).

at least three animals emerged twice in the 3week period. Average curved carapace length and width were $96 \mathrm{~cm} \pm 4$ and $83 \mathrm{~cm} \pm 4$ (mean \pm standard error, five records), respectively.

Track records over the study period are shown in Figure 3. Table 2 shows the total tracks recorded on each beach section. $\mathrm{K} 2$ and $\mathrm{K} 3$ had 314 emergence tracks, producing an

Table 1. Percentage success of nesting on Kazanli beaches, 2-21 July 1990 from observations of emerging C. mydas

\begin{tabular}{|c|c|c|c|c|c|c|c|}
\hline Beach & $\begin{array}{l}\text { No. of } \\
\text { nights of } \\
\text { records }\end{array}$ & $\begin{array}{l}\text { Total no. } \\
\text { emerging }\end{array}$ & $\begin{array}{l}{ }^{\mathrm{U}^{\prime} \text {-turn }} \\
\text { (no } \\
\text { digging) }\end{array}$ & $\begin{array}{l}\text { Failed } \\
\text { nest } \\
\text { attempts }\end{array}$ & $\begin{array}{l}\text { Successful } \\
\text { nests }\end{array}$ & $\begin{array}{l}\text { No. of } \\
\text { nest } \\
\text { attempts }\end{array}$ & $\begin{array}{l}\text { Percentage of } \\
\text { successful } \\
\text { nest attempts }\end{array}$ \\
\hline $\mathrm{K} 1$ & 2 & 2 & 0 & 1 & 1 & 2 & - \\
\hline K2 & 15 & 9 & 2 & 5 & 2 & 7 & 28.57 \\
\hline K3 & 15 & 113 & 15 & 63 & 35 & 98 & 35.71 \\
\hline K4 & 2 & 2 & 1 & 0 & 1 & 1 & - \\
\hline Total & 19 & 126 & 18 & 69 & 39 & 108 & 36.11 \\
\hline
\end{tabular}

Table 2. Percentage success of nesting on Kazanli beaches, 2-21 July 1990, from C. mydas track records

\begin{tabular}{|c|c|c|c|c|c|c|c|}
\hline Beach & $\begin{array}{l}\text { No. of } \\
\text { nights of } \\
\text { records }\end{array}$ & $\begin{array}{l}\text { Total no. } \\
\text { emerging }\end{array}$ & $\begin{array}{l}\text { 'U'-turn } \\
\text { (no } \\
\text { digging) }\end{array}$ & $\begin{array}{l}\text { Failed } \\
\text { nest } \\
\text { attempts }\end{array}$ & $\begin{array}{l}\text { Successful } \\
\text { nests }\end{array}$ & $\begin{array}{l}\text { No. of } \\
\text { nest } \\
\text { attempts }\end{array}$ & $\begin{array}{l}\text { Percentage of } \\
\text { successful } \\
\text { nest attempts }\end{array}$ \\
\hline K1 & 2 & 5 & 3 & 1 & 1 & 2 & - \\
\hline $\mathrm{K} 2$ & 20 & 28 & 11 & 15 & 2 & 17 & 11.76 \\
\hline $\mathrm{K} 3$ & 20 & 286 & 72 & 156 & 58 & 214 & 27.10 \\
\hline K4 & 4 & 6 & 3 & 2 & 1 & 3 & - \\
\hline Total & 20 & 325 & 89 & 174 & 62 & 236 & 26.27 \\
\hline
\end{tabular}




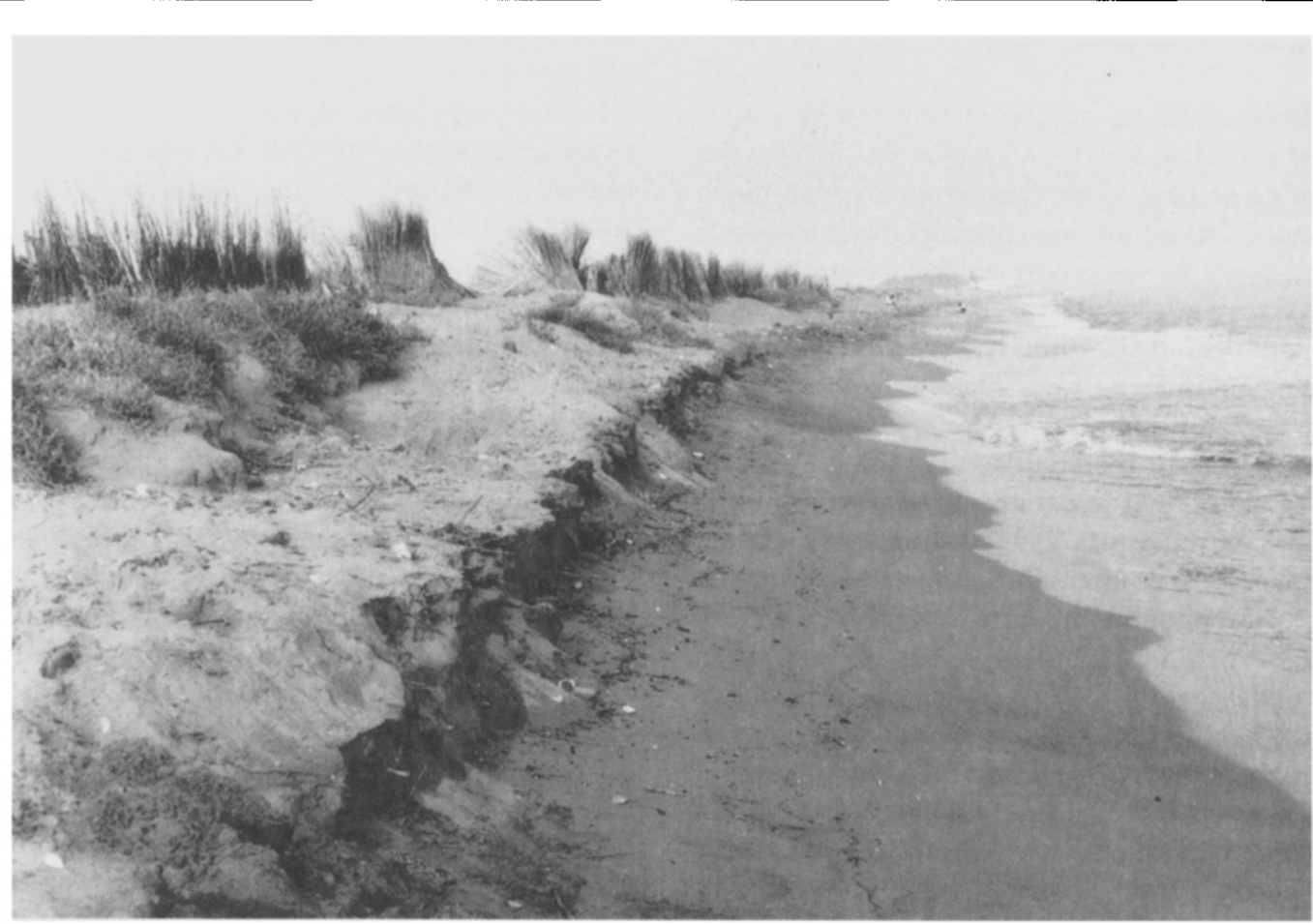

Erosion at the west end of Kazanli III (K3).

estimated 60 nests, equating to only 19.1 per cent nesting success. Track records collected by the team from Dokus Eylül University at Izmir ( $H$. Durmus, unpubl. data) have been combined with this data from this project (Table 3 ) and show that between 2 July and 12 August 1990, at least 491 emergences occurred, resulting in an estimated 76 nests on the four beaches ( 15.5 per cent success). This low nesting success explains the large number of abandoned body pits found by the prelimi- nary survey. Although 427 turtles were estimated to emerge on the 605-m-long K3 during the season, nesting density was estimated at 0.12 nests per metre of shoreline. There was no evidence of eggs being dug up during nest excavation, but on several occasions turtles were observed disturbing each other when nesting ( $\mathrm{S}$. Coley, pers. obs). Two records were made of adult $C$. caretta emerging on $\mathrm{K} 2$ and at least two $C$. caretta nests had hatched by 12 August (H. Durmus, pers. comm.).

Table 3. Numbers of C. mydas estimated from tracks on Kazanli beaches for the period 2 July-12 August (including $\mathrm{H}$. Durmus, unpubl. data)

\begin{tabular}{lccccc}
\hline Beach & $\begin{array}{l}\text { No. of } \\
\text { nights of } \\
\text { records }\end{array}$ & $\begin{array}{l}\text { Total no. } \\
\text { emerging }\end{array}$ & $\begin{array}{l}\text { No. of } \\
\text { successful } \\
\text { nests }\end{array}$ & $\begin{array}{l}\text { Percentage } \\
\text { of turtles } \\
\text { that nest }\end{array}$ & $\begin{array}{l}\text { No. } \\
\text { emerging } \\
\text { per night }\end{array}$ \\
\hline K1 & 9 & 15 & 2 & 13.3 & 1.7 \\
K2 & 40 & 40 & 2 & 5.0 & 1.0 \\
K3 & 40 & 427 & 70 & 16.4 & 10.7 \\
K4 & 5 & 9 & 2 & 22.0 & 1.8 \\
Total & 41 & 491 & 76 & 15.4 & 12.0 \\
\hline
\end{tabular}


Assessment of nesting beaches

Most successful nesting attempts were situated on $K 3$, at the dune base or just behind the ridge of sand along the top of the man-made dune. This dune is artificially high and nest attempts in steep regions failed due to sand collapsing from above. Agricultural encroachment behind the dune has resulted in vegetation binding the sand together, reducing the available nesting area. The area available for nesting is further reduced by the collapse of the fence that separates the dune from the agricultural areas behind. Emerging hatchlings face a gradient that slopes away from the sea and photopollution from street and factory lights behind the beach. Successful excavation of egg chambers by C. mydas was rare unless just behind the dune ridge, and experimental excavation found damp sand was absent above $55 \mathrm{~cm}$. Of 11 attempts to excavate a man-made 'nest' on K3, six were successful. Those that failed were in locations where dry sand was still present below $45 \mathrm{~cm}$, which suggests that sand moisture content may be a problem. The west of $\mathrm{K} 3$ is subject to erosion, which is probably caused by a change in currents following construction of the jetty. There is some concern over possible agglomeration of sand on $\mathrm{K} 3$ due to chemical effects of effluent released from the factory (C. Whitmore, pers. comm.).

Few people use K3 in the day and, although line-fishermen often sleep on the beach, turtles are rarely disturbed at night. Fishing boats often set nets during the night, running from the east of $\mathrm{K} 3$ to the edge of K2. Two C. mydas were killed by fishermen during the project, probably because they were entangled in nets. The fence that separates $\mathrm{K} 3$ and the agricultural area to the north is in poor condition and causes problems for nesting C. mydas. Some dig under the fence and nest on the agricultural side, or become trapped. On the beach, sand falls into body-pits during excavation when turtles dig up against the fence (Smart and Coley, 1990) The factory is the main cause of photopollution on K3 and street lamps situated behind $\mathrm{K} 2$ are visible on the man-made dune. Traffic frequently uses the road behind
$\mathrm{K} 1$ at night and headlights pan across both $\mathrm{K} 3$ and $\mathrm{K} 2$.

K1 supports large numbers of ghost crabs Ocypode cursor, which are known to cause heavy hatchling mortality (Stancyk, 1982). Although turtles on $\mathrm{K} 1$ have an apparently higher nesting success than on other Kazanli beaches, low numbers emerge on this beach and hatchlings are likely to suffer from heavy predation. On K2, street lamps and a bar at the west end cast light over the beach until early in the morning. Dogs were seen on K2 on several nights, although no evidence of nest predation was seen. Tracks show that dogs also visit nests on K3. A considerable amount of litter on $\mathrm{K} 1, \mathrm{~K} 2$ and $\mathrm{K} 3$ could present a hazard to hatchlings moving towards the sea.

K4 suffers from photopollution at its west end (due to poorly screened lights), predation of hatchlings from dogs (D. Gücük, pers. comm.), and effluent discharging on to the beach. During the project, the General Manager of the Soda Sanayii factory arranged for discharge pipes to be extended so that effluent would not concentrate on the beach where hatchlings emerge. He also arranged for fencing to isolate the beach from local dogs, and screening of lights. The possible modification of the jetty between $\mathrm{K} 3$ and $\mathrm{K} 4$ to halt erosion is currently under discussion with Soda Sanyaii (C. Whitmore, pers. comm).

\section{Discussion}

The 1988 survey estimated that 70 per cent of emerging turtles nested successfully, (Sarigul and Langeveld, 1988). Table 2 suggests that approximately 27 per cent of emerging turtles nested successfully on $\mathrm{K} 3$ and this is supported by observations. The success rate of 36 per cent estimated from observations on $\mathrm{K} 3$ (Table 1) will be an overestimate because turtles that fail to nest spend less time on the beach and are seen less frequently. The authors believe that the decline in nesting success between 1988 (Sarigul and Langeveld, 1988) and 1990 is too great to be attributable to different methods of estimation of numbers of nests. This difference is considered to be a real change in 
nesting density. The authors suggest that changes in the chemical composition of the sand and loss of nesting area on the beach (to erosion and agriculture) have contributed to the reduction in nesting success since 1988. An extension of the tagging programme (or a basic numbering of emerging turtles) is suggested to estimate the number of C. mydas. using the Kazanli beaches and hence accurately establish the size of the nesting population and nesting success. Research is also required to establish the number of emerging hatchlings and the effects of predation. However, any research must take second place to the priorities for conserving the beach itself: halting erosion; shielding photopollution; reclaiming agricultural land; reshaping artificial dunes; and restricting fishing, chemical pollution and litter on the nesting beaches.

\section{Acknowledgments}

The authors would like to thank everyone who helped the project in the UK and Turkey, particularly Hakan, Oguz and Adem from Dokus Eylül University, Izmir, for all their help at Kazanli and the information they supplied. Also thanks to Nergis Yazgan and Gernant Magnin of the DHKD. The project was self-funded with assistance from DHKD, University of Leicester Street Fund, Department of Zoology, University of Leicester, and PDI Systems Limited. Finally, special thanks to Yusef and to Clare and Keith.

\section{References}

Anon., 1990. Problems for turtle protection on Zakynthos. Oryx, 24, 188.

Arianoutsou, M. 1988. Assessing the impacts of human activities on nesting of loggerhead sea-turtles (Caretta caretta L.) on Zakynthos island, Western Greece. Environmental Conservation, 15, 327-334.

Baran, I. and Kasparek, M. 1989. Marine Turtles in Turkey. Status Survey 1988 and Recommendations for
Conservation and Management. WWF Report.

Demetropoulos, A. and Haddjichristophorou, M. 1989. Sea turtle conservation in Cyprus. Marine Turtle Newsletter, 44, 4-6.

Groombridge, B. 1990. Marine Turtles in the Mediterranean: Distribution, Population Status, Conservation. Report to the Council of Europe Environment Conservation and Management Division. World Conservation Monitoring Centre, Cambridge, UK.

Groombridge, B. and Whitmore, C. 1989. Marine turtle survey in northern Cyprus. Marine Turtle Newsletter, 47, 5-8.

Margaritoulis, D. 1982. Observations on loggerhead sea turtle Caretta caretta activity during three nesting seasons (1977-1979) in Zakynthos, Greece. Biological Conservation, 24, 193-204.

Sarigul, G. and Langeveld, M. 1988. Sea Turtles Nesting on the Beaches of South-East Turkey. Unpublished preliminary report to the Society for the Protection of Nature (DHKD) in Turkey.

Sella, I. 1982. Sea Turtles in the Eastern Mediterranean and Northern Red Sea. In Biology and Conservation of Sea Turtles (ed. K. A. Bjorndal), pp. 417-425. Smithsonian Institution Press, Washington DC.

Smart, A.C. and Coley, S.J. 1990. Kazanli Turtle Project 1990. Unpublished report to DHKD. (Available from Royal Geographical Society Map Room and University of Leicester Library).

Stancyk, S.E. 1982. Non-human predators of sea turtles and their control. In Biology and Conservation of Sea Turtles (ed. K. A. Bjorndal), pp. 139-153. Smithsonian Institution Press, Washington DC.

Warren, L. and Antonopoulou, E. 1990. The conservation of loggerhead turtles in Zakynthos, Greece. Oryx, 24, 15-23.

Whitmore, C., Sarigul, G. and Yazgan, N. 1990. New legislation to protect sea turtle nesting areas in Turkey at Patara, the Goksu Delta and Ekincik. Marine Turtle Newsletter, 50, 6-7.

Stephanie J. Coley, Department of Zoology, University of Leicester, University Road, Leicester LE1 7RH, UK.

Andrew C. Smart, Durrell Institute of Conservation and Ecology, University of Kent, Canterbury, Kent CT2 7NX, UK. 